\title{
Penampilan Produksi Penggemukan Feedlot Sapi Persilangan Simental-Ongole Jantan Diberi Ransum Menir Kedelai-Minyak Ikan Lemuru Terproteksi
}

\author{
J. Riyanto*, S.D. Widyawati, A. Pramono, Lutojo dan Riyanti \\ Program Studi Peternakan, Fakultas Pertanian, Universitas Sebelas Maret
}

\begin{abstract}
ABSTRAK
Penelitian ini bertujuan untuk mengetahui pengaruh penggunaan menir kedelai dan minyak ikan lemuru terproteksi dalam ransum terhadap performa sapi persilangan Simental-Peranakan Ongole (Simpo) jantan. Materi yang digunakan adalah 9 ekor dengan rata-rata bobot awal 467,55 $\pm 30,89 \mathrm{~kg}$. Desain penelitian yang digunakan adalah rancangan acak lengkap (RAL) yang terdiri dari 3 perlakuan dan 3 kali ulangan. Perlakuan yang diberikan yaitu P0 = jerami padi fermentasi $30 \%+$ konsentrat basal 70\%; P1 = jerami padi fermentasi 30\% + konsentrat basal 55\% + menir kedelai tidak terproteksi dan minyak ikan lemuru 15\%; P2 = jerami padi fermentasi 30\% + konsentrat basal 55\% + menir kedelai terproteksi dan minyak ikan lemuru15\%. Data dianalisis menggunakan analisis variansi dan dilanjutkan dengan uji Duncan Multiple Range Test. Hasil penelitian menunjukkan bahwa penggunaan menir kedelai dan minyak ikan lemuru terproteksi dalam ransum tidak berpengaruh terhadap berat awal, berat akhir, PBB, PBBH, FCR dan FER namun berbeda nyata terhadap konsumsi bahan kering namun penerimaan usaha mengalami peningkatan. Simpulan dari penelitian ini adalah penggunaan menir kedelai dan minyak ikan lemuru terproteksi sebanyak $15 \%$ dalam ransum mampu meningkatkan penampilan produksi dan penerimaan serta income over feed cost penggemukan feedlot sapi persilangan Simmental-Peranakan Ongole jantan.
\end{abstract}

Kata Kunci: Menir kedelai, Minyak ikan lemuru, Penampilan produksi, Proteksi formaldehid, Sapi Simmental-Peranakan Ongole

\section{Production Performances of Males Simental Ongole Crossbred Cattle Fed by Protected Soybean Groats-Lemuru Fish Oil in the Diet}

\begin{abstract}
This study was aimed to determine the effect of protected soybean groats-Lemuru fish oil in the diet on performance of males Simental Ongole Crossbred. The materials used in this study were 9 heads of males Simental Ongole Crossbred cattle with an average initial weight of $467.55 \pm 30.89 \mathrm{~kg}$. The experimental design used was a completely randomized design (CRD) consisting 3 treatments and 3 replications. The treatments were $P 0=30 \%$ rice straw fermentation $+70 \%$ basal concentrate; $P 1=30 \%$ rice straw fermentation $+55 \%$ basal concentrate $+15 \%$ ogf unprotected soybean groats-lemuru fish oil, and $P 2=P 1=30 \%$ rice straw fermentation $+55 \%$ basal concentrate $+15 \%$ of protected soybean groats-lemuru fish oil. Data were analyzed using analysis of variance followed by Duncan's Multiple Range Test. The results showed that the use of protected soybean groats-lemuru fish oil in the diet did not affect the initial body weight, final body weight, average daily gain, FCR and FER. Additionally, the treatment significantly affected dry matter intake and the income of the feedlot has increased. Conclusions of this study was the use of $15 \%$ protected soybean groats-lemuru fish oil in the diet increased production performance and income of male simental Ongole Crossbred feedlot.
\end{abstract}

Keywords: Formaldehid protected, Lemuru fish oil, Production performance, Simental Ongole crossbred, Soybean groats

\section{PENDAHULUAN}

Produktivitas sapi potong yang tinggi dapat dicapai apabila kebutuhan nutriennya tercukupi, diantaranya adalah protein dan energi. Kedua hal tersebut merupakan komponen utama yang mendukung peningkatan produktivitas sapi potong. Bahan pakan yang dapat digunakan untuk meningkatkan produktivitas sapi potong adalah menir kedelai sebagai sumber protein dan minyak ikan lemuru sebagai sumber energi (Perdhana et al., 2013 dan Wibowo et al., 2012).

Menir kedelai merupakan pecahan kedelai atau bisa disebut dengan hasil sortiran kedelai utuh (Pujiati, 2010). Menir kedelai mengandung protein yang tinggi yaitu diatas 35\% (Astuti, 2014), tetapi sifatnya mudah

\footnotetext{
*Penulis Korespondensi: J. Riyanto

Alamat: Jl. Ir. Sutami 36A Kentingan, Surakarta, Jawa Tengah

E-mail: jokoriyanto@staff.uns.ac.id
}

terdegradasi di dalam rumen. Protein di dalam rumen akan terdegradasi menjadi amonia, peptida dan asam amino, sedangkan protein yang lolos dari proses degradasi akan diserap di dalam usus halus (Sajati et al., 2012). Salah satu upaya yang dapat dilakukan agar protein yang terkandung di dalam menir kedelai dapat diserap lansung pada usus halus adalah dengan teknologi proteksi menggunakan formaldehid (Tiven et al., 2015). Prinsip dasar kerja formaldehid terhadap protein adalah pada suasana tingkat keasaman yang rendah seperti di rumen ( $\mathrm{pH}$ sekitar 6), formaldehid akan membentuk ikatan dengan protein sehingga lebih tahan terhadap degradasi mikroba rumen (Parakkasi et al., 1994). Ikatan formaldehid dengan protein selanjutnya akan terlepas di abomasum akibat $\mathrm{pH}$ abomasum yang rendah ( $\mathrm{pH}$ sekitar 3 ).

Minyak ikan lemuru merupakan sumber lemak yang mengandung sekitar $25 \%$ asam lemak jenuh dan $75 \%$ asam lemak tak jenuh (Sestilawarti et al., 2013). Lemak adalah sumber energi yang lebih tinggi 
dibandingkan dengan karbohidrat atau protein. Pemberian minyak ikan lemuru pada pakan ternakdapat meningkatkan kandungan energi pakan. Nilai energi lemak sedikitnya dua kali lebih besar daripada karbohidrat (Wina dan Susana, 2013). Kandungan lemak dalam ransum tidak akan mengganggu metabolisme ruminal bila penggunaanya tidak melebihi 5\% dari bahan kering ransum (Wibowo et al., 2012).

Penggunaan menir kedelai dan minyak ikan lemuru terproteksi dengan level tertentu dalam ransum sapi Simpo tidak menurunkan konsumsi bahan kering, serat kasar, NDF dan ADF. Konsumsi pakan yang tidak menurun tersebut diharapkan mampu meningkatkan performa sapi Simpo (Perdhana et al., 2013). Berdasarkan uraian di atas, maka perlu dilakukan penelitian mengenai pengaruh penggunaan menir kedelai dan minyak ikan lemuru terproteksi dalam ransum terhadap performa sapi persilangan Simental-Peranakan Ongole (Simpo) jantan.

Penelitian ini bertujuan untuk mengetahui pengaruh penggunaan menir kedelai terproteksi dan minyak ikan lemuru terhadap performa penggemukan feedlot sapi persilangan Simental-Peranakan Ongole (Simpo) jantan.

\section{MATERI DAN METODE}

\section{Materi}

Sapi yang digunakan dalam penelitian ini adalah sapi persilangan Simmental-Peranakan Ongole (Simpo) jantan berjumlah 9 ekor dengan bobot badan rata-rata 467,55 $\pm 30,89 \mathrm{~kg}$. Ransum yang digunakan dalam penelitian ini terdiri dari jerami padi fermentasi, menir kedelai, minyak ikan lemuru dan konsentrat basal. Konsentrat basal terdiri dari bekatul, pollard, kulit kopi, bungkil sawit, mineral dan molases. Jumlah pakan yang diberikan adalan $3 \%$ dari total bobot badan. Perbandingan antara jerami padi fermentasi dan konsentrat adalah 30 : 70 sebagai pakan kontrol, sedangkan untuk ransum perlakuan menggunakan campuran menir kedelai dan minyak ikan lemuru dengan perbandingan 4:1 diproteksi menggunakan formaldehid kadar 37\%. Pemberian air minum dilakukan secara ad libitum. Pemberian pakan selama
85 hari. Kandungan nutrien bahan pakan penyusun ransum dapat dilihat pada Tabel 1, serta susunan dan kandungan nutrien ransum perlakuan pada Tabel 2.

\section{Desain Penelitian}

Desain penelitian menggunakan Rancangan Acak Lengkap (RAL) dengan tiga perlakuan (P0, P1, dan P2), masing-masing perlakuan di ulang sebanyak 3 kali dan masing-masing ulangan terdiri dari 1 ekor sapi. Adapun perlakuannya adalah sebagai berikut :

- $\quad \mathrm{P} 0=$ jerami padi fermentasi $30 \%+$ konsentrat basal 70\%;

- $\quad \mathrm{P} 1=$ jerami padi fermentasi $30 \%+$ konsentrat basal 55\% + menir kedelai dan minyak ikan lemuru tidak terproteksi $15 \%$;

- $\quad \mathrm{P} 2=$ jerami padi fermentasi $30 \%+$ konsentrat basal $55 \%+$ menir kedelai dan minyak ikan lemuru terproteksi $15 \%$

Bahan yang digunakan dalam pembuatan jerami padi fermentasi adalah jermi padi 1 ton, starbio $1 \mathrm{~kg}$, molases 1 liter, stimulator plus 1 liter dan urea $1 \mathrm{~kg}$. Proses pembuatan proteksi menir kedelai adalah menir kedelai dibuat tepung, tepung menir kedelai diproteksi menggunakan formaldehid kadar $37 \%$ pemberian $1 \%$ dari bahan kering dan diperam selama 1 jam, tepung menir kedelai dicampur dengan minyak ikan lemuru sampai merata, menjemur campuran menir kedelai di bawah sinar matahari sampai kering.Harga ransum P0 sebesar Rp 1.974,-, P1sebesar Rp 2.322,-, dan P2 sebesar Rp 2.344,-.

\section{Parameter Produksi}

Parameter produksi meliputi (1) Berat awal (kg) diperoleh dengan menimbang berat badan sapi saat awal penelitian satuan $\mathrm{kg}$, (2) Berat akhir (kg) diperoleh dengan menimbang berat badan abdan sapi saat selesai penelitian satuan $\mathrm{kg}$, (3) Pertambahan berat badan $(\mathrm{kg})$ diperoleh dengan menghitung selisih berat badan akhir dan awal sapi, (4) Pertambahan berat badan harian $(\mathrm{kg} / \mathrm{ekor} / \mathrm{hari})$ diperoleh dari bobot badan akhir dikurangi bobot badan awal $(\mathrm{kg})$ dibagi dengan lama waktu pemeliharaan (Rumiyati, 2008), (5) Konsumsi pakan bahan kering (kg/ekor/hari) dihitung dengan cara mengurangi total pemberian

Tabel 1. Kandungan nutrien bahan pakan perlakuan

\begin{tabular}{lccccccc}
\hline \hline \multirow{2}{*}{ Bahan pakan } & \multicolumn{7}{c}{ Kandungan nutrien (\%) } \\
\cline { 2 - 8 } & BK & PK & EE & SK & ABU & BO & BETN $^{(1)}$ \\
\hline Jerami padi fermentasi $^{\text {a }}$ & 91,45 & 7,44 & 0,70 & 28,68 & 17,61 & 82,39 & 45,57 \\
Kulit kopi $^{\text {a }}$ & 88,41 & 4,70 & 0,94 & 31,69 & 7,39 & 92,61 & 55,28 \\
Bungkil sawit $^{\text {a }}$ & 91,45 & 12,03 & 7,36 & 11,02 & 4,86 & 95,14 & 64,73 \\
Bekatul $^{\mathrm{a}}$ & 91,85 & 6,71 & 2,03 & 23,45 & 3,09 & 96,91 & 64,72 \\
Pollard $^{\mathrm{a}}$ & 89,63 & 10,03 & 3,59 & 7,35 & 14,31 & 85,69 & 64,72 \\
Mineral $^{\text {a }}$ & 100 & 0,00 & 0,00 & 0,00 & 0,00 & 0,00 & 0,00 \\
Molases $^{\text {b }}$ & 87,50 & 3,1 & 0,00 & 0,00 & 0,00 & 0,00 & 0,00 \\
Meniklemu tidak terproteksi $^{\text {a }}$ & 92,75 & 22,03 & 28,59 & 9,88 & 7,40 & 92,60 & 32,10 \\
Meniklemu terproteksi $^{\text {a }}$ & 91,38 & 24,70 & 27,80 & 8,15 & 7,09 & 92,91 & 32,26 \\
\hline
\end{tabular}

Keterangan: a. Hasil analisis Lab. Nutrisi dan Makanan Ternak Fakultas Pertanian, Universitas Sebelas Maret Surakarta (2015)

b. Siregar (2003)

1) $\operatorname{BETN}(\%)=100 \%-(\%$ air $+\%$ abu $+\%$ serat kasar $+\%$ lemak kasar $+\%$ protein kasar $($ Kamal, 1994). 
Tabel 2. Susunan dan kandungan nutrien ransum perlakuan

\begin{tabular}{|c|c|c|c|}
\hline Nama Bahan Pakan & P0 & P1 & $\mathrm{P} 2$ \\
\hline & & ---- \% ------ & \\
\hline Jerami Padi fermentasi & 30,00 & 30,00 & 30,00 \\
\hline Bekatul & 26,55 & 20,86 & 20,86 \\
\hline Pollard & 11,75 & 9,23 & 9,23 \\
\hline Kulit kopi & 11,59 & 9,10 & 9,10 \\
\hline Bungkil sawit & 18,33 & 14,40 & 14,40 \\
\hline Mineral & 0,77 & 0,61 & 0,61 \\
\hline Molases & 1,01 & 0,80 & 0,80 \\
\hline $\begin{array}{l}\text { Menir kedelai:minyak ikan (4:1) } \\
\text { tidak terproteksi }\end{array}$ & 0 & 15,00 & 0 \\
\hline $\begin{array}{l}\text { Menir kedelai:minyak ikan ( } 4: 1) \\
\text { terproteksi }\end{array}$ & 0 & 0 & 15,00 \\
\hline Jumlah & 100 & 100 & 100 \\
\hline \multicolumn{4}{|l|}{ Kandungan nutrien } \\
\hline Protein kasar (\%) & 7,97 & 10,05 & 10,45 \\
\hline Lemak kasar (\%) & 2,63 & 6,40 & 6,28 \\
\hline Serat kasar (\%) & 21,39 & 20,13 & 19,87 \\
\hline $\mathrm{BO}(\%)$ & 88,69 & 88,87 & 88,91 \\
\hline BETN (\%) & 56,73 & 52,32 & 52,34 \\
\hline $\operatorname{TDN}(\%)^{(1)}$ & 64,69 & 69,55 & 69,74 \\
\hline
\end{tabular}

Sumber : Hasil perhitungan dari Tabel 1. ${ }^{(1)}$ Berdasarkan rumus persamaan-persamaan regresi untuk memperkiraan Total Digestible Nutrient seseuai rumus Sutardi (2001) cit Widodo et al. (2012).

pakan dengan sisa pakan dalam satu hari, dikonversikan ke dalam bahan kering dan dinyatakan dalam kg/ekor/hari (Wijaya, 2008), (6) Feed convertion ratio atau konversi pakan merupakan perbandingan antara jumlah konsumsi pakan berdasarkan bahan kering dengan pertambahan bobot badan selama pemeliharaan (Wijaya, 2008), (7) Feed efficieny ratio atau efisiensi pakan merupakan nilai yang diperoleh dari pertambahan bobot badan yang dihasilkan per unit bahan kering ransum yang dikonsumsi (Nanda et al., 2014), (8) Feed cost per gain atau biaya pakan setiap pertambahan berat badan harian diperoleh dengan cara menghitung jumlah biaya pakan yang diperlukan untuk menghasilkan pertambahan bobot badan (Wijaya, 2008).

\section{Analisa Usaha}

Analisis usaha dilakukan dengan mengamati (1) Penerimaan per ekor per hari diperoleh dari hasil pertambahan berat badan harian dikalikan dengan harga berat sapi hidup per $\mathrm{kg}$, (2) Total konsumsi pakan diperoleh dari hasil penimbangan total pakanyang dikonsumsi selama penelitian berdasaran bahan kering, (3) Total biaya pakan diperoleh dengan mengalikan total pakan yang dikonsumsi dengan biaya pakan per kg, (4) Total penerimaan diperoleh dengan cara total pertambahan berat badan selama penelitian dengan harga sapi hidup, (5) Total pendapatan diluar biaya pakan atau income over feed cost (IOFC) diperoleh dengan cara mengurangi total penerimaan dengan total biaya pakan.

\section{Analisis Data}

Semua data yang diperoleh dalam penelitian dianalisis dengan menggunakan analisis variansi untuk mengetahui adanya pengaruh perlakuan terhadap parameter penampilan produksi kecuali parameter analisis usaha yang dianalisi secara deskritif. Model matematika yang digunakan adalah sebagai berikut :

$$
\mathrm{Y}_{\mathrm{ij}}=\mu+\tau_{\mathrm{i}}+\varepsilon_{\mathrm{ij}}
$$

Keterangan :

$\mathrm{Y}_{\mathrm{ij}}=$ Nilai pengamatan (perlakuan ke-I dan ulangan ke-j)

$\mu \quad=$ Nilai tengah umum

$\tau_{\mathrm{i}}=$ Pengaruh perlakuan ke-i

$\varepsilon_{\mathrm{i}}=$ Galat percobaan pada perlakuan ke-i dan ulangan ke-j

Apabila hasil analisis variansi terdapat pengaruh perlakuan, dilanjutkan dengan uji lanjut DMRT (Ducan's Multiple Range Test) untuk mengetahui perbedaan antar perlakuan (Steel dan Torrie, 1995).

\section{HASIL DAN PEMBAHASAN}

\section{Penampilan Produksi}

Penampilan produksi sapi persilangan Simmental Peranakan Ongole (Simpo) pada berbagai perlakuan perbedaan pengunaan menir kedelai dan minyak ikan lemuru terproteksi tertera pada Tabel 3.

Hasil analisis variansi menunjukkan bahwa pertambahan bobot badan harian $(\mathrm{PBBH})$ sapi penelitian berbeda tidak nyata $(\mathrm{P}>0,05)$. Penggunaan menir kedelai dan minyak ikan lemuru terproteksi dalan ransum Sapi Simpo jantan tidak mempengaruhi PBBH. Pertambahan bobot badan merupakan manifestasi dari sejumlah nutrien ransum dikonversi menjadi daging (Yulianti, 2007).

Pada Tabel 3 tampak bahwa pertambahan bobot badan harian sapi Simpo jantan mengalami kenaikan. 
Tabel 3. Penampilan produksi sapi pesilangan simental peranakan ongole (simpo) pada berbagai perbedaan pakan

\begin{tabular}{|c|c|c|c|}
\hline \multirow[t]{2}{*}{ Ulangan } & \multicolumn{3}{|c|}{ Perlakuan } \\
\hline & P0 & P1 & $\mathrm{P} 2$ \\
\hline Berat awal (kg) & $466 \pm 56,06$ & $461,33 \pm 28,11$ & $475,33 \pm 18,79$ \\
\hline Berat akhir (kg) & $533,33 \pm 34,57$ & $534 \pm 36,77$ & $552,67 \pm 6,18$ \\
\hline Pertambahan berat badan $(\mathrm{kg})$ & $67,33 \pm 3,66$ & $72,67 \pm 15,88$ & $77,33 \pm 14,27$ \\
\hline $\begin{array}{l}\text { Pertambahan berat badan harian } \\
(\mathrm{kg} / \mathrm{ekor} / \mathrm{hari})^{\mathrm{ns}}\end{array}$ & $0,79 \pm 0,04$ & $0,85 \pm 0,19$ & $0,91 \pm 0,17$ \\
\hline $\begin{array}{l}\text { Konsumsi pakan bahan kering } \\
\text { (kg/ekor/hari) }\end{array}$ & $12,83 \pm 0,70^{\mathrm{a}}$ & $10,73 \pm 0,90^{\mathrm{b}}$ & $11,39 \pm 0,10^{\mathrm{ab}}$ \\
\hline Feed Convertion Ratio ${ }^{\mathrm{ns}}$ & $16,26 \pm 1,39$ & $12,95 \pm 1,99$ & $12,98 \pm 2,54$ \\
\hline Feed Efficiency Ratio ${ }^{\text {ns }}$ & $0,06 \pm 0,01$ & $0,08 \pm 0,01$ & $0,08 \pm 0,01$ \\
\hline
\end{tabular}

Keterangan : ${ }^{\mathrm{a}, \mathrm{b}, \mathrm{c}}$ superskrip yang berbeda pada baris yang sama menunjukkan perbedaan yang nyata $(\mathrm{P}<0,05)$, ns (non signifant) $=$ berbeda tidak nyata $(\mathrm{P}>0,05)$. $\mathrm{P} 0=$ jerami padi fermentasi 30\% + Konsentrat basal 70\%; P1 = jerami padi fermentasi 30\% + Konsentrat basal 55\% + menir kedelai tidak terproteksi dan minyak ikan lemuru 15\%; P2 = jerami padi fermentasi 30\% + Konsentrat basal $55 \%+$ menir kedelai terproteksi dan minyak ikan lemuru $15 \%$.

Pertambahan bobot badan harian P1 dan P2 lebih tinggi bila dibandingkan dengan P0, walaupun secara statistik perbedaan itu tidak nyata. P0 bila dibandingkan dengan P1 pertambahan bobot badan hariannya mengalami kenaikan sebesar 7,06\%, P0 dengan P2 sebesar 13,19\% dan P1 dengan P2 sebesar $6,59 \%$. Hasil tersebut menunjukkan bahwa pakan P2 yaitu menir kedelai terproteksi dan minyak ikan lemuru mampu menghasilkan pertambahan bobot badan yang lebih tinggi bila dibandingkan dengan perlakuan yang lain. Pakan menir kedelai terproteksi formaldehid dan minyak ikan lemuru (P2) menghasilkan $\mathrm{PBBH}$ yang paling tinggi. Hal tersebut diduga protein di dalam pakan terlindungi dari degradasi mikrobia rumen, sehingga protein lolos dan terabsorbsi di usus halus yang kemudian dimanfaatkan tubuh ruminansia untuk pertumbuhan. Tubuh memerlukan protein untuk memperbaiki dan mengganti sel-sel yang rusak untuk kepentingan produksi (Akoso, 1996). Protein dengan ketahanan degradasi rumen rendah perlu dilindungi agar sebagian proteinnya dapat mencapai pasca rumen, sehingga dapat memasok asam amino bagi ruminansia (Puastuti, et al., 2006).

Rata-rata pertambahan bobot badan harian antara P0, P1, dan P2 berturut-turut yaitu $0,79 \pm 0,04$, $0,85 \pm 0,19$ dan $0,91 \pm 0,17$. Hasil penelitian sebelumnya oleh Yakin et al. (2012) didapatkan hasil bahwa pertambahan bobot badan harian sapi Simpo yang diberi pakan silase isi rumen berbeda tidak nyata. PBBH yang dihasilkan sebesar 0,95 kg/ekor/hari.

Hasil penelitian menunjukkan bahwa konsumsi pakan dari ketiga perlakuan berturut-turut yaitu $\mathrm{P} 0=$ $12,83 \pm 0,70, \mathrm{P} 1=10,73 \pm 0,90$ dan $\mathrm{P} 2=11,39 \pm 0,10$ menunjukkan perbedaan yang nyata $(\mathrm{P}<0,05)$. Hasil uji Duncan's menunjukkan terdapat perbedaan yang nyata antara perlakuan $\mathrm{P} 0$ dan $\mathrm{P} 1$, sedangkan $\mathrm{P} 0$ dengan $\mathrm{P} 2$ dan $\mathrm{P} 1$ dengan $\mathrm{P} 2$ berbeda tidak nyata. Rata-rata konsumsi bahan kering (BK) P0 = $12,83 \pm 0,70$ dan $\mathrm{P} 1=10,73 \pm 0,90$. Konsumsi merupakan jumlah pakan yang dimakan oleh ternak yang akan digunakan untuk mencukupi kebutuhan hidup pokok dan produksi (Setyowati, 2005). Hasil tersebut menunjukkan bahwa sapi memiliki tingkat konsumsi yang berbeda. Pada penelitian ini terdapat perbedaan yang nyata antaran tingkat konsumsi P0 dan P1, dimana pakan P0 merupakan pakan kontrol, sedangkan Pladalah pakan perlakuan yang mendapatkan tambahan menir kedelai tanpa proteksi dan minyak ikan lemuru. Tingkat konsumsi pakan P0 lebih tinggi bila dibandingkan dengan P1. Hal tersebut diduga pakan P1 masih menimbulkan bau minyak ikan lemuru, sehingga menyebabkan tingkat palatabilitas ternak menjadi menurun. Palatabilitas adalah tingkat kesukaan ternak terhadap pakan yang diberikan (Haryanti, 2009). Perbedaan jenis bahan pakan yang menyusun ransum dapat menimbulkan perbedaan palatabilitas dan kandungan nutrien yang pada akhirnya menyebabkan perbedaan jumlah pakan yang dikonsumsi oleh ternak (Nusi, 2011).

Selain faktor diatas, kandungan nutrien pakan juga mempengaruhi tingkat konsumsi ternak. Pakan P1 memiliki kandungan TDN dan protein kasar lebih tinggi bila dibandingkan dengan pakan $\mathrm{P} 0$, oleh karena itu terjadi perbedaan konsumsi. Kandungan nutrien bahan pakan yaitu TDN dan protein kasar dalam ransum dapat mempengaruhi tingkat konsumsi ternak. Hal tersebut disebabkan karena semakin tinggi energi pakan maka akan menurunkan konsumsi dan sebaliknya, apabila semakin rendah nilai energi dalam pakan, maka akan meningkatkan konsumsi pakan (Huda, 2008).

Rata-rata konversi pakan pada perlakuan P0, P1 dan P2 secara berturut turut adalah 16,26 $\pm 1,39$, $12,95 \pm 1,99,12,98 \pm 2,54$. Ketiga perlakuan tersebut menunjukkan adanya penurunan nilai konversi pakan. Nilai konversi pakan tertinggi terdapat pada perlakuan P0 yaitu sebesar $16.26 \pm 1.70$. Hasil analisis variansi menunjukkan bahwa konversi pakan dari penelitian ini adalah berbeda tidak nyata $(\mathrm{P}>0,05)$. Penggunaan menir kedelai terproteksi dan minyak ikan lemuru dalan ransum sapi Simpo jantan tidak mempengaruhi konversi pakan. Konversi pakan sering digunakan untuk melihat keefisienan ransum, semakin rendah 
Tabel 4. Penampilan analisa usaha sapi silangan Simental Peranakan Ongole (Simpo) pada berbagai perbedaan pakan

\begin{tabular}{lccc}
\hline \hline \multicolumn{1}{c}{ Parameter } & \multicolumn{3}{c}{ Perlakuan } \\
\cline { 2 - 4 } & P0 & P1 & P2 \\
\hline Penerimaan per ekor per hari (Rp) & 35.647 & 38.471 & 40.941 \\
Total biaya pakan (Rp) & 2.150 .698 & 2.118 .057 & 2.268 .817 \\
Total penerimaan (Rp) & 3.030 .000 & 3.270 .000 & 3.480 .000 \\
Total pendapatan diluar biaya pakan atau IOFC (Rp) & 879.302 & 1.151 .943 & 1.211 .183 \\
\hline
\end{tabular}

Keterangan: P0 = jerami padi fermentasi 30\%+ Konsentrat basal 70\%; P1 = jerami padi fermentasi 30\%+ Konsentrat basal 55\% + menir kedelai tidak terproteksi dan minyak ikan lemuru 15\%; P2 = jerami padi fermentasi 30\% + Konsentrat basal 55\% + menir kedelai terproteksi dan minyak ikan lemuru $15 \%$ proteksi. IOFC adalah income over feed costs.

nilai konversi ransum semakin efisien ransum tersebut diubah menjadi produk ternak (Yulianti, 2007).

Besar kecilnya nilai konversi ransum dipengaruhi oleh PBBH dan konsumsi BK bahan pakan (Yakin, 2012). Hasil analisis variansi berbeda tidak nyata tersebut diduga karena tingkat konsumsi BK menunjukkan perbedaan yang nyata, tetapi $\mathrm{PBBH}$ yang dihasilkan berbeda tidak nyata, sehingga nilai konversi tidak terjadi perbedaan. Hal ini menunjukkan bahwa menir kedelai terproteksi dan minyak ikan lemuru belum dapat menaikkan bobot badan ternak secara signifikan dengan jumlah pakan yang dikonsumsi. Selain itu, diduga level penggunaan menir kedelai terproteksi dan minyak ikan lemuru dalam ransum belum optimal.

Hasil analisis variansi yang berbeda tidak nyata tersebut menunjukkan tidak adanya perbedaan dalam memanfaatkan $1 \mathrm{~kg}$ pakan untuk menghasilkan $1 \mathrm{~kg}$ bobot badan diantara perlakuan. Sapi membutuhkan konsumsi BK sebesar 12,95-16,29 kg untuk menghasilkan $1 \mathrm{~kg}$ bobot badan. Hasil pada penelitian ini nilai konversi ransum lebih tinggi bila dibandingkan hasil penelitian sebelumnya. Penelitian yang dilakukan oleh Laila (2011) didapatkan hasil bahwa penggunaan kelapa sawit dan minyak ikan lemuru terproteksi dalam ransum sapi Simpo jantan menghasilkan konversi pakan sebesar 7,52.

Rata-rata efisiensi pakan pada perlakuan P0, P1, dan P2 secara berturut- turut adalah $0,06 \pm 0,01$, $0,08 \pm 0,01$ dan $0,08 \pm 0,01$. Ketiga perlakuan menunjukkan terjadinya kenaikan nilai efisiensi ransum, yang tertinggi terdapat pada perlakuan P2 yaitu sebesar $0,08 \pm 0,02$. Hasil analisi variansi pada tabel 7.menunjukkan perbedaan yang tidak nyata $(\mathrm{P}>0,05)$.Penggunaan menir kedelai terproteksi dan minyak ikan lemuru dalan ransum sapi Simpo jantan tidak mempengaruhi efisiensi pakan.

Efisiensi pakan adalah nilai yang diperoleh dari pertambahan bobot badan yang dihasilkan per unit bahan kering ransum yang terkonsumsi (Akbar, 2007). Besar kecilnya nilai efisiensi pakan dipengaruhi oleh PBBH dan pakan yang di konsumsi oleh ternak. Semakin tinggi nilai efisiensi ransum maka jumlah ransum yang diperlukan untuk menghasilkan satu kilogram daging semakin sedikit (Setyowati, 2005).

Hasil analisis variansi menunjukkan pemberian menir kedelai terproteksi formaldehid dan minyak ikan lemuru menghasilkan efisiensi ransum yang sama dengan pakan kontrol. Hal tersebut diduga konsumsi pakan ternak belum dapat menghasilkan pertambahan bobot badan harian ternak secaran signifikan, sehingga menyebabkan nilai dari efisiensi ransum berbeda tidak nyata. Penggunaan menir kedelai terproteksi dan minyak ikan lemuru pada penelitian ini adalah $15 \%$ dari total ransum, diduga level yang digunakan dalam ransum belum optimal. Efisiensi pakan berkaitan dengan nilai konversi pakan. Efisensi pakan yang rendah disebabkan rendahnya rerata $\mathrm{PBBH}$ dan rendahnya nilai nutrien bahan pakan yang dikonsumsi sapi (Nurdiati et al., 2012).

Hasil penelitian sebelumnya oleh Nurdiati et al. (2012) didapatkan hasil bahwa sapi Simpo yang diberi pakan hijauan berupa legum dan limbah pertanian menghasilkan efisiensi pakan sebesar 0,02, sehingga bila dibandingkan dengan penelitian sebelumnya efisiensi pakan pada penelitian ini lebih tinggi.

\section{Analisis Usaha}

Penampilan parameter analisis usaha sapi Silangan Simental Peranakan Ongole (Simpo) pada berbagai perlakuan perbedaan pengunaan menir kedelai dan minyak ikan lemuru terproteksi tertera pada Tabel 4.

Rata-rata penerimaan per ekor per hari pada $\mathrm{P} 0$, P1 dan P2 hasil penelitian secara berturut-turut adalah Rp. 35.647; Rp. 38.471; dan Rp. 40.941. Penerimaan disebut juga pendapatan kotor, yaitu total hasil dikalikan harga pada saat itu (Soekartawi, 1986). Hasil penelitian menunjukkan ternak yang diberi pakan perlakuan berupa menir kedelai terproteksi maupun tidak terproteksi dan minyak ikan lemuru menghasilkan penerimaan yang lebih tinggi bila dibandingkan dengan pakan kontrol. Besarnya kenaikan penerimaan antar perlakuan yaitu P0 dengan $\mathrm{P} 1$ sebesar 7,3\%, P0 dengan P2 sebesar 12, 9\% dan P1 dengan $\mathrm{P} 2$ sebesar 6\%.

Pakan menir kedelai terproteksi dan minyak ikan lemuru (P2) menghasilkan penerimaan yang paling tinggi dari ketiga perlakuan. Hal tersebut disebabkan karena P2 menghasilkan pertambahan bobot badan harian yang tinggi bila dibandingkan dengan P0 dan P1, sehingga menyebabkan terjadinya peningkatan penerimaan. Besar kecilnya penerimaan peternak dipengaruhi oleh produk yang diperoleh dari usaha 
ternak sapi, yaitu berupa pertambahan bobot badan harian ternak dan harga produk, yaitu harga jual daging per kilo bobot hidup (Zulfanita, 2011).

Nilai ekonomi ransum perlakuan dihitung berdasarkan total pendapatan diluar biaya pakan atau income over feed cost (IOFC). Income over feed cost (IOFC) merupakan jumlah pendapatan yang dihasilkan setelah dikurangi dengan biaya pakan (Pitono, 2014). Rata-rata IOFC pada P0, P1 dan P2 adalah Rp. 879.302; Rp. 1.151.943; dan Rp. 1.211.183. Hasil penelitian menunjukkan dari ketiga perlakuan didapatkan hasil P0 memiliki nilai IOFC yang lebih rendah daripada P1 dan P2. Nilai IOFC dihitung berdasarkan dua faktor yaitu pendapatan dan pengeluaran. Pendapatan diperoleh berdasarkan dua faktor yaitu pertambahan bobot badan dan harga jual ternak sedangkan pengeluaran berdasarkan harga ransum dan konsumsi ransum (Setyowati, 2005). Sehingga dalam penentuan nilai IOFC dipengaruhi oleh bobot badan, harga jual ternak, harga ransum dan konsumsi ransum. Pada penelitian ini didapatkan hasil bahwa perlakuan P0 memiliki nilai PBBH dan IOFC yang lebih rendah bila dibandingkan dengan perlakuan P1 dan P2.Tampak pula bahwa penerimaan per ekor perhari P0 lebih rendah namun total konsumsinya lebih tinggi dari pada $\mathrm{P} 1$ dan $\mathrm{P} 2$. Hal tersebut memperlihatkan bahwa penggunaan menir kedelaiminyak ikan leuru terproteksi lebh efisien dalam menghasilkan produksi pertamabahan berat badan sehingga mampu meningkatkan pendapatan dan IOFC.

\section{KESIMPULAN}

Penggunaan menir kedelai dan minyak ikan lemuru terproteksi formaldehid sebanyak 15\% dalam ransum mampu meningkatkan penampilan produksi dan penerimaan serta income over feed cost penggemukan feedlot sapi persilangan SimmentalPeranakan Ongole jantan.

\section{DAFTAR PUSTAKA}

Akbar, S. A. 2007. Pemanfaatan tandan kosong sawit fermentasi yang dikombinasikan dengan defaunasi dan protein by pass rumen terhadap performans ternak domba. Jurnal Pengembangan Peternakan Tropis 32(2): 80-85.

Akoso, B. T. 1996. Kesehatan Sapi. Kanisius. Yogyakarta

Astuti, S. T. 2014. Evaluasi Menir Kedelai Terproteksi Ditinjau dari Kecernaan Nutrien secara In Vitro. Skripsi. Program Studi Peternakan. Universitas Sebelas Maret. Surakarta.

Haryanti, N. W. 2009. Kualitas Pakan dan Kecukupan Nutrisi Sapi Simental di Peternakan Mitra Tani Andini, Kelurahan Gunung Pati, Kota Semarang. Laporan Praktek Kerja Lapangan. Jurusan Nutrisi dan Makanan Ternak. Fakultas Peternakan. Universitas Diponegoro. Semarang
Huda, R. H. 2008. Pengaruh Penggunaan Ampas Tempe dalam Ransum terhadap Performan Domba Lokal Jantan. Skripsi. Program Studi Peternakan. Universitas Sebelas Maret. Surakarta.

Laila, A. Z. 2011. Pengaruh Penggunaan Minyak Kelapa Sawit dan Minyak Ikan Lemuru Terproteksi dalam Ransum terhadap Performa Sapi Simmental - Peranakan Ongole Jantan. Skripsi. Program Studi Peternakan. Universitas Sebelas Maret. Surakarta

Nanda, D. D., A. Purnomoadi dan L. K. Nuswantara. 2014. Penampilan produksi sapi bali yang diberi pakan dengan berbagai level pelepah sawit. Agromedia 32(2): 52-63.

Nurdiati, K., E. Handayanta dan Lutojo. 2012. Efisiensi produksi sapi potong pada musim kemarau di peternakan rakyat daerah pertanian lahan kering kabupaten gunungkidul. Journal Tropical Animal Husbandry 1(1): 52-58.

Nusi, M., R. Utomo dan Soeparno. 2011. Pengaruh penggunaan tongkol jagung dalam complete feed dan suplementasi undegraded protein terhadap pertambahan bobot badan dan kualitas daging pada sapi peranakan ongole. Buletin Peternakan 35(3): 173-181.

Parakkasi, A. M. Yamin. I. K. G. Wiryawan., R. Priyanto dan R. S. Budi. 1994. Produksi wol domba jantan priangan pada pemberian pakan mengandung bungkil kelapa sawit yang telah diproteksi formaldehid. Media Peternakan 24(2): 38-44.

Perdhana, P. W., J. Riyanto., A. Ratriyanto., S. D. Widyawati dan W. P. S. Suprayogi. 2013. Pengaruh penggunaan tepung ikan dan menir kedelai terproteksi dalamransum terhadap kecernaan nutrien pada sapi persilangan simmental peranakan ongole jantan. Journal Tropical Animal Husbandry 2(1): 1-7.

Pitono, A. C, Harya Nugroho, Kuswati Dan T. Susilawati. 2014. Dalam Skripsi. Performa Sapi Brahman Cross Steer Warna Merah Dan Putih Pada Fase Finisher. Universtas Brawijaya. Malang.

Puastuti, W., I. W. Mathius dan D. Yulistiani. 2006. Bungkil kedelai terproteksi cairan batang pisang sebagai pakan imbuhan ternak domba: in sacco dan in vivo. Jurnal Ilmu Ternak dan Veteriner 11(2): 106-115.

Pujiati, A. 2010. Pengaruh Menir Kedelai, Tepung Ikan Dan Bungkil Kelapa Sawit Terproteksi Terhadap Kecernaan Bahan Kering, Bahan Organik dan Protein Kasar Ransum Sapi PO Berfistula. Skripsi. Program Studi Peternakan. Universitas Sebelas Maret. Surakarta

Rumiyati. 2008. Pengaruh Imbangan Jerami Kacang Tanah dengan Rumput Raja dalam Ransum terhadap Performan Sapi Peranakan Friesian Holstein (PFH) Jantan. Skripsi. Program Studi Peternakan. Universitas Sebelas Maret. Surakarta 
Sajati, G., B. W. H. E. Prasetyo dan Surono. 2012. Pengaruh ekstrusi dan proteksi dengan tani $n$ pada tepung kedelai terhadap produksi gas total dan metan secara in vitro. Animal Agricultural Journal 1(1): 242-256.

Sestilawarti. Mirzah dan Montesqrit. 2013. Pengaruh pemberian mikrokapsul minyak ikan dalam ransum puyuh terhadap performa produksi. Jurnal Peternakan Indonesia 15(1): 69-74.

Setyowati, A. D. 2005. Pengaruh Limbah Media Produksi Jamur Pelapuk Kayu Isolat Hs terhadap Konsumsi, Produksi dan Efisiensi Pakan pada Ternak Domba. Skripsi. Program Studi Nutrisi dan Makanan Ternak. Fakultas Peternakan. Institut Pertanian Bogor. Bogor

Tiven, N. C., L. M. Yusiati. Rusman dan U. Santoso. 2015.Pengaruh proteksi cpo dengan formaldehid terhadap kecernaan dan performa domba ekor tipis. Buletin Peternakan 39 (2): 78 - 83.

Wibowo, M. S., M. D. Efendi., S. D. Widyawati., Lutojo., J. Riyanto dan W. P. S. Suprayogi. 2012. Pengaruh suplementasi minyak ikan lemuru dan minyak kelapa sawit terproteksi dalam ransum terhadap performan dan kualitas kimia daging domba lokal jantan. Journal Tropical Animal Husbandry 1(1): 67-74.

Wijaya, A. 2008. Pengaruh Imbangan Hijauan dengan Konsentrat Berbahan Baku Limbah Pengolahan Hasil Pertanian dalam Ransum terhadap Penampilan Sapi PFH Jantan. Skripsi. Program Studi Peternakan. Universitas Sebelas Maret. Surakarta.

Wina, E dan I. W. R. Susan. 2013. Manfaat lemak terproteksi untuk meningkatkan produksi dan reproduksi ternak ruminansia. Wartazoa 23(4): 176-183.

Yakin, E. A., N. Ngadiyono dan R. Utomo. 2012. Pengaruh substitusi silase isi rumen sapi pada pakan basal rumput dan konsentrat terhadap kinerja sapi potong. Buletin Peternakan 36(3): $174-180$,

Yulianti, A., U. Hidayat dan T. R. Tawaf. 2007. Production Performance Of Australian Commercial Cross (Acc) Steer That Given Ration Based On Rice Straw Result Of Aerobic Microbe Bioprocess. International Seminar Biotechnology. Bandung.

Zulfanita. 2011. Kajian analisis usaha ternak kambing di desa Lubangsampang kecamatan Pituruh kabupaten Purworejo. Mediagro 7(2): 61-68. 